\title{
ALTERNATIVE APPROACHES FOR SOLID WASTE MANAGEMENT: A CASE STUDY IN FAISALABAD PAKISTAN
}

\author{
Hafsa Yasin ${ }^{*}$, Muhammad Usman ${ }^{1}$, Haroon Rashid ${ }^{1}$, Abdul Nasir and Ijaz Ahmad Randhawa ${ }^{2}$ \\ 1 Department of Structures and Environmental Engineering, University of Agriculture Faisalabad, Pakistan ${ }^{2}$ Head of Department, \\ Civil Engineering Department, University of Faisalabad, Pakistan. \\ *Corresponding author's e-mail: hafsayasin6@gmail.com
}

This is an open access article distributed under the Creative Commons Attribution License, which permits unrestricted use, distribution, and reproduction in any medium, provided the original work is properly cited

ARTICLE DETAILS ABSTRACT

Article history:

Received 25 August 2017 Accepted 20 October 2017 Available online 7 November 2017

Keywords:

Solid waste management, Composting Recycling, Incineration
Management of solid waste is one of the current issues especially in cities due to increasing population and modern lifestyle. Faisalabad produces almost 1300-1600 tons of solid waste per day which is going to be increase with the passage of time. $56 \%$ of generated waste is collected only and $43 \%$ is disposed in open dumping site without any precautionary measures and treatment. It results in many kinds of environmental deterioration and become a source of communicable diseases. This study was conducted to estimate the potential present in solid waste of Faisalabad. Recycling, composting and incineration are alternative approaches to solid waste management. By managing the solid waste, it reduces the pollution problems with the outcomes of valuable fertilizer and energy. Composition of Faisalabad waste depicts valuable quantity of energy in it.

\section{INTRODUCTION}

Waste production is continuously in advancing trend as a consequence of increasing population, migrating to urban areas, and monetary growth [1]. The generation of waste is still rising swift as compared to rate of urbanization [2]. Worldwide MSW production depicted a tremendous increase barely among 10 years from 0.68 billion tons per year (2000) to 1.3 billion tons per year (2010). Additionally, the prediction has been made that it will go rise up to 2.2 billion per year in 2025 and 4.2 billion per year in 2050 [3]. Across the last two decagons, per capita waste productivity expand treble in developed countries which is 5 to 6 times more than that in developing countries [4]. This enormous burden of waste if not suitably organized and disposed will surely pose an unfavorable and detrimental impacts on the different components of ecosystem and environment [5]. Acute issues related to the management of MSW have been found in various cities of Malaysia [6], Bangladesh [7], India [8], Thailand [9] and China [10] as a result of fast development in trend of migration to cities, population and industrial sectors.

Globally there are four choices that can be taken into account for the imperishable management of solid waste. It includes Recycling, Landfilling with energy recapturing, Biological method and Thermal treatment. By treating waste it does not only manage but also produce energy in different forms so it is also called waste to energy (WtE) approach [11].

In developing countries like Pakistan MSW sectors are withstanding different difficulties in the various steps of solid waste management due to lack of expertise, resources and mismanagement. According to MOE Pakistan, in cities more than 54,850 tons of waste per day is produced averagely while unluckily $50 \%$ is only collected due to mismanagement [12]. Open burning, open dumping and landfills are common practices in Pakistan [13]. Open Dumping affects the natural equilibrium in many ways. It provides a very good place for vectors to survive and breed its generation and affects the human in a number of ways like dengue, malaria etc. especially to the nearby residents of dumping site. Leachate causes high TDS and damages the ground water quality. Vegetation is being affected by this method of waste disposal. Cough and respiration problems are significant due to throwing of waste as untreated. It gives rise to land pollution and litter as well. Sometimes the burning of waste heaps or piles is a source of air pollution due to release of toxic gases. The main aim of this research is to study the feasibility of different alternatives for managing the solid waste of Faisalabad with respect to present availability of resources and expertise.

\section{DESCRIPTION OF THE STUDY AREA}

Faisalabad a well-known city for its textile production generates almost 1300-1600 tons per day that is production rate of four towns only while the collection efficiency is $56 \%$ and disposing efficiency is $43 \%$ only [14]. The Faisalabad Waste Management Company collects the solid waste from four towns through different vehicles and disposes to the dumping site. It is called Muhammada Wala dumping site which is located at Muhammada Wala near Central Jail, Jaranwala road. Geographically it lies at latitude of 310 23'8' N and longitude of 730 14' 26" E at $182.93 \mathrm{~m}$ above sea level with area of almost 75 acres. There are piles of waste on the whole area. The trucks unload the waste on the area without any treatment.

\section{MATERIAL AND METHODS}

The quantity and composition of waste are important parameters to be known for the suitable management of solid waste. The constitution of waste and quantity differs from one area to other area due to difference in lifestyle, cultural and utilization habits [15].

\subsection{Composition of Waste}

Waste is a mixture of different components that includes organic and inorganic materials. The waste at the open dumping constitutes almost $60 \%$ organic substances (wood $1.07 \%$, paper and cardboard $7.67 \%$, textile $6.53 \%$, animal waste $2.34 \%$, bones $2.4 \%$ and food waste $33.81 \%$ ) while almost $8 \%$ recyclables in a form of plastic and metals [14].

\subsection{Strategy for MSW management in Faisalabad}

It constitutes the following steps

\subsection{1) Generation}

Segregation at the source of generation is the best option to be adopted for the better management of solid waste while sometimes it is difficult to achieve due to unawareness and unfamiliarity of the public to segregation. It will help in processing and transferring of waste.

\subsection{2) Collection of Waste}

Waste collection by hand carts and animal carts from door to door are the current practices in Faisalabad. They collect commingles waste and then carry to transfer station of respective town or block. This system can be modified by firstly marking specific points in different localities of town to place or install disposal bins for different types of waste. The bins can be classified for organic (especially kitchen waste), plastic and rubber, paper and cardboard and others. They should be of different color and must be 
tag in both languages Urdu and English. This strategy is very helpful for governmental and private sectors of waste collection. Then they just have to transport to the transfer stations.

\subsection{3) Transfer Stations}

The different types of segregated waste from bins will carry to the transfer stations on different vehicles or in vehicles of different partition to minimize the chances of mixing waste. There are 13 transfer station in Faisalabad. Every town has its different transfer stations as shown below. At the transfer station further segregation will take place that were left by individuals of homes. At the station shredding and compaction of different waste should be there. For example, shredding of organic waste should take place in order to increases the efficiency of composting mechanism. Compaction of paper, cardboard or plastic will increase the space and helpful in recycling process.

Table1: Collection Points of Different towns of Faisalabad

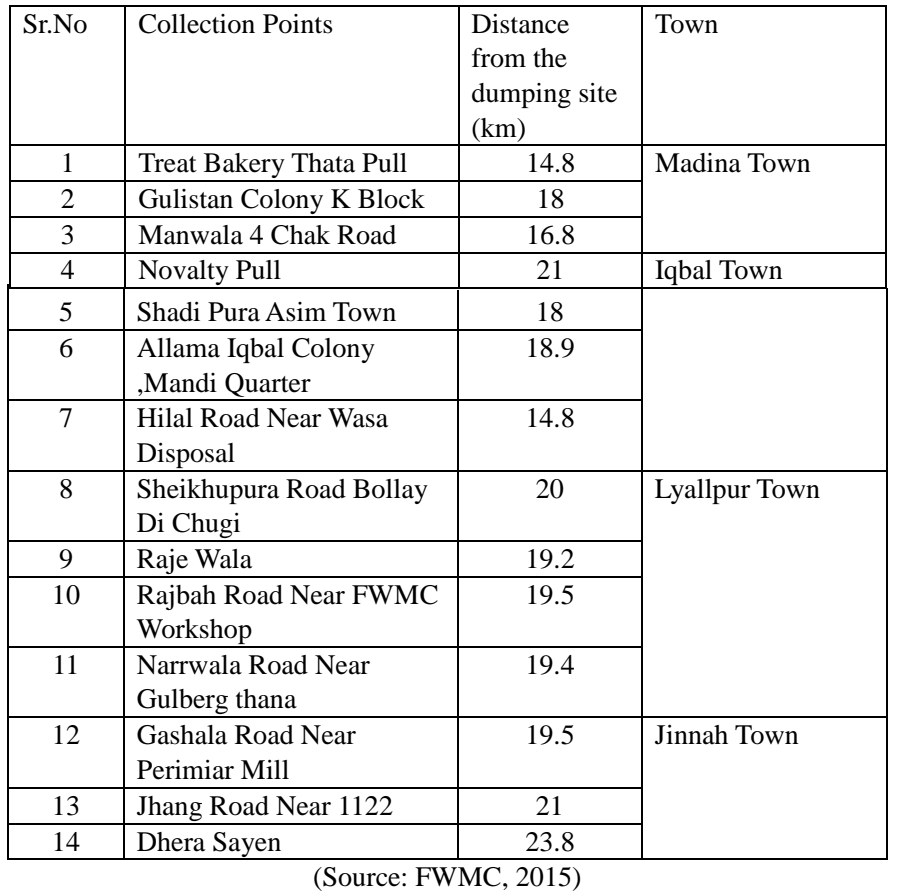

\subsection{4) Different Processing options (Possible ways of MSW} management w.r.t Faisalabad Conditions)

Composting, recycling and controlled sanitary landfill are most suitable options according to the proportions of different components in the waste. As almost $60 \%$ waste can be composted, while $8 \%$ can be recycled into different products where product quality does not matter. The remaining proportion of waste like stones or bricks can be reused in the filling of construction work. If stones, bricks are not in a condition to be used they can disposed in a land fill with in controlled conditions.

\section{a) Composting}

It is the favorable way of solid waste management due to high ratio of organic material present in the waste [15]. It is actually a natural process of decomposition of organic material under controlled conditions with the help of microorganism which can be developed naturally or can be injected into a stable or complex form [16]. The final product can be used as fertilizer if it is prepared with high degree of concern. Besides, producing fertilizer, it manages the $60 \%$ portion of waste by reducing its volume. If it is not concerned to produce high degree of fertilizer product, the final humus can be easily filled in any empty spaces to make ground level or it can be disposed easily in the sanitary land fill. The volume reduction by composting can help to increase the life of landfill side.

\section{b) Recycling}

The plastic and metal proportion of waste for example tins, bottles cans etc. should be recycled. They should be made into the products where high degree of product quality is not required like hangers, bottles, plastic bins etc. The waste at the dumping site has almost $8 \%$ potential to recycle the products.

\section{c) Incineration: waste to energy an alternative approach}

Incineration requires high expertise and funds to accomplish but waste has high potential to produce energy because waste is the useful wealth at the invalid place in incorrect form and inexact forum. It is the blazing of the waste in controlled conditions like oxygen enrich environment and many others etc. and change into some sort of energy [17]. Heating values of materials is important parameter to be known for estimating the potential of energy in the waste. The quantity of heat emitted by igniting the material is known as heating value [18].

\section{d) Disposal}

If the humus substance created after composting is of good quality it can be used as fertilizer. If it is not meeting the artificial fertilizer in different aspects it can be used in various purposes. For example, in levelling the certain structures, filling material. However, the research is going on in this aspect. It can be safely disposed in sanitary landfill without the danger of leachate. On the other hand, the ash residues left after incineration significantly reduces the volume of waste and it is also safely disposed in sanitary landfill.

\section{FINDINGS}

Typical values of heat of waste component is given below

Table: 2 Heat Values of Different Waste

\begin{tabular}{|c|c|c|}
\hline Sr.No & $\begin{array}{l}\text { Components of } \\
\text { Waste }\end{array}$ & $\begin{array}{l}\text { Typical Heat } \\
\text { Values (btu/lb.) }\end{array}$ \\
\hline 1 & Food Waste & 2000 \\
\hline 2 & Paper and cardboard & 7000 \\
\hline 3 & Plastic & 14000 \\
\hline 4 & Textile & 7500 \\
\hline 5 & Rubber & 10000 \\
\hline 6 & Garden Trimmings & 2800 \\
\hline 7 & Wood & 8000 \\
\hline 8 & Glass & 60 \\
\hline 9 & Metals & 300 \\
\hline 10 & Dust, Ashes, Bricks & 3000 \\
\hline
\end{tabular}

The energy capacity in the waste can be estimated by multiplying the heat value of particular waste to its ratio present in the waste.

Table 3: Energy Estimation of Different Waste

\begin{tabular}{|l|l|c|l|}
\hline $\begin{array}{l}\text { Componen } \\
\text { ts of } \\
\text { Waste }\end{array}$ & $\begin{array}{l}\text { Soli } \\
\text { d } \\
\text { Was } \\
\text { te \% }\end{array}$ & $\begin{array}{l}\text { Heating } \\
\text { Values } \\
\text { (Btu/lb.) }\end{array}$ & $\begin{array}{l}\text { Total } \\
\text { energy } \\
\text { contributio } \\
\text { n (Btu/lb.) }\end{array}$ \\
\hline $\begin{array}{l}\text { Food } \\
\text { Waste }\end{array}$ & $\begin{array}{l}33.8 \\
1\end{array}$ & 2000 & 67620 \\
\hline $\begin{array}{l}\text { Paper and } \\
\text { Cardboard }\end{array}$ & 7.67 & 7000 & 53690 \\
\hline Plastic & 3.30 & 14000 & 46200 \\
\hline Textile & 6.53 & 7500 & 48975 \\
\hline Rubber & 3.30 & 10000 & 33,000 \\
\hline $\begin{array}{l}\text { Garden } \\
\text { Trimmings }\end{array}$ & 7.36 & 2800 & 20608 \\
\hline Wood & 1.07 & 8000 & 8560 \\
\hline Glass & 2.43 & 60 & 145.8 \\
\hline Metals & 1.0 & 300 & 300 \\
\hline $\begin{array}{l}\text { Dust, } \\
\text { ashes, } \\
\text { bricks }\end{array}$ & 28.7 & 3000 & 86370 \\
\hline $\begin{array}{l}\text { Total energy contribution } \\
\text { (Btu/lb.) }\end{array}$ & & $365,468.8$ \\
\hline
\end{tabular}

If whole waste is incinerated, it will have a $365,468.8 \mathrm{Btu} / \mathrm{lb}$. of energy that can be produced.

\section{DISCUSSION}

Solid waste management is the critical concern now-a-days due to raising pollution and different health problems. By considering the different parameters and conditions related to Faisalabad scenarios composting, recycling and incineration are possible options. One is to adopt composting technique for those portions of organic waste that has high nitrogen content for example vegetable waste, blood and fish scraps etc. so that it will be used as valuable fertilizer. Secondly waste that can be used 
again by passing some sort of processes should be recyclables so that the huge quantity of plastic and rubber can be reduced. Old used plastic items can be recycled to various objects or items where high quality is not important e.g. hangers, holders etc. Waste to energy is an alternative for solid waste management i.e. incineration technique. It may be the combustion of commingled waste or may be some portion or kind of waste in order to produce energy for some useful purpose like electricity but it requires expertise and funding but it depicts the significant energy potential present in it

\section{RECOMMENDATION}

- High priority is always given to Community health in planning and designing of solid waste management.

- Open dumping must be prohibited in order to reduce the pollution problems.

- $\quad$ The waste carrying vehicle must be covered so that the littering problem willreduce.

- The government and private sector must go ahead for better management of waste.

- Awareness should be spread as soon as possible about the segregation importance and usage of different bins.

- $\quad$ High penalty will be given to those who litter and workers who neglect duties during collection and transporting of waste.

\section{REFERENCES}

[1] Ali, S.M., Pervaiz, A., Afzal, B., Hamid, N. and Yasmin, A. 2014. Open dumping of municipal solid waste and its hazardous impacts on soil and vegetation diversity at waste dumping sites of Islamabad city. Journal of King Saud University, 26, 56-65.

[2] Islam, K. M. N. 2016. Municipal Solid Waste to Energy Generation in Bangladesh: Possible Scenarios to Generate Renewable Electricity in Dhaka and Chittagong City. Journal of Renewable Energy, pp. 16.

[3] Hoornweg, D., and Bhada-Tata, P. 2012. What a waste: a global review of solid waste management. World Bank 15.

[4] UNEP. 2005b. Solid Waste Management, Nairobi, Kenya United Nations Commission on Human Settlement (UNCHS).

[5] Scarlet, N., Motola, V., Dallemand, J.F., Monforti, F. and Mofor, L. 2015. Evaluation of energy potential of municipal solid Waste from African urban areas. Renewable and Sustainable Energy Reviews, 50, 1269-1286.

[6] Johari, A., Ahmed, S.I., Hashim, H., Alkali, H. and Ramli, N. 2012. Economic and environmental benefits of landfill gas from municipal solid waste in Malaysia. Renewable and Sustainable Energy Reviews, 16 (5) 2907-2912.

[7] Bhuiyan, S.H. 2010. A crisis in governance: urban solid waste management in Bangladesh. Habitat International, 34 (1), 125-133.

[8] Singh, R.P., Tyagi, V.V., Allen, T., Ibrahim, M.H. and Kothari, R. 2011. An overview for exploring the possibilities of energy generation from municipal solid waste (MSW) in Indian scenario. Renewable and Sustainable Energy Reviews, 15 (9), 4797-4808.

[9] Chiemchaisri, C, and Visvanathan, C. 2008. Greenhouse gas emission potential of the municipal solid waste disposal sites in Thailand. Journal of the Air and Waste Management Association, 58 (5), 629-635.

[10] Cheng, H., and Hu, Y. 2010. Municipal solid waste (MSW) as a renewable source of energy: current and future practices in China. Bio resource Technology, 101 (11) 3816-3824.

[11] Shekdar, A. V. 2009. Sustainable solid waste management: an integrated approach for Asian countries. Waste Management, 29 (4), 14381448 .

[12] Ejaz, N., and Janjua, N.S. 2012. Solid Waste Management Issues in Small Towns of Developing World: A Case Study of Taxila City. International Journal of Environmental Science and Development, 3, 167-171.

[13] Domestic Solid Waste Management in Pakistan. 2002. Japan International Corporation Agency (JICA).

[14] FWMC. 2015. Action Plan to Expand Solid Waste Management Services to the Entire City Area. Faisalabad Waste Management Company.

[15] World Bank Report.2012. What a waste: a global review of solid waste management http://siteresources.worldbank.org/ INTURBANDEVELOPMENT/Resources/3363871334852610766/ Chap3 .pdf (last accessed on 22-05-16)

[16] Lim, S., Lee, L. and Wu, T. 2016. Sustainability of using composting and vermicomposting technologies for organic solid waste biotransformation: recent overview, greenhouse gases emissions and economic analysis. Journal of Cleaner Production, 111, 262-278.

[17] Islam, K.M.N. 2016. Municipal Solid Waste to Energy Generation in Bangladesh: Possible Scenarios to Generate Renewable Electricity in Dhaka and Chittagong City. Journal of Renewable Energy, 6, 1-16.

[18] https://en.wikipedia.org/wiki/Heat_of_combustion(last accessed on 06-06-2016) 